\title{
FORAMINIFERAL PALEOENVIRONMENTAL ANALYSIS OF TERTIARY FINING-UPWARD CYCLES IN THE EASTERN U.S.
}

\author{
GIBSON, Thomas G., Department of Paleobiology, National Museum of Natural \\ History, MRC 121, Smithsonian Institution, Washington, DC 20560, U.S.A.
}

Numerous fining-upward cycles occur in Eocene, Miocene, and Pliocene inner to middle neritic deposits of the U.S. eastern Gulf and Atlantic Coastal Plains. These cycles usually have a rapidly gradational change from shelly, slightly to heavily glauconitic, largely sandy sediment in the lower part to clay dominated beds containing few shells, no glauconite, and sparse to abundant organic matter in the upper part. Some of these cycles have been considered as third order sequences, others as parasequences. The fining-upward cycles commonly are attributed to upward shallowing in water depths and/or progradation of shallower water sediments.

Foraminiferal assemblages, however, suggest that most or all parts of a cycle were deposited in a similar bathymetric range. The sandy, lower parts contain assemblages indicative of more oxygenated conditions; the clayey upper parts have a large increase of species indicative of lowered oxygen conditions. The foraminiferal assemblage changes, combined with changes observed in other biologic groups and in sedimentary characteristics, suggest that although both parts of the cycle were deposited in shallow, open marine environments, the upper part formed during times of increased discharge of freshwater runoff that contained a largely clay load and probably increased nutrients. The surficial freshwater wedge caused a stratified water column in shallow marine environments. The water stratification, when combined with the influx of abundant terrestrial debris and nutrients, resulted in lowered oxygen conditions in bottom waters. The suggested increase in precipitation, possibly associated with an increase in temperature, may have caused increased vegetative cover in the sediment source area during the influx of clay-rich sediments in the upper part of the cycles. These changes in conditions may represent climatic changes occurring during Milankovich cycles. 